\title{
Case of gluteal haematoma in the setting of dual antiplatelet overlapping with tumoural calcinosis of the hip
}

\author{
Ahmed Abdalla, ${ }^{1}$ Thair Dawood, ${ }^{2}$ Ghassan Bachuwa ${ }^{1}$
}

${ }^{1}$ Hurley Medical Center, Flint, Michigan, USA

${ }^{2}$ Departent of Internal

Medicine, Hurley Medical

Center, Flint, Michigan, USA

\section{Correspondence to}

Dr Ghassan Bachuwa,

gbachuw2@hurleymc.com

Accepted 5 February 2017

\section{DESCRIPTION}

A woman aged 40 years with medical history of end-stage renal disease (ESRD) on haemodialysis. Eight months earlier to this presentation, she underwent coronary angioplasty with two drug-eluting stents due to myocardial infarction. She had been on aspirin and ticagrelor since that time. She presented to the emergency department with severe sudden-onset left hip pain. She did not recall any trauma or any precipitating factors. She had severe tenderness around her left hip joint with marked decreased range of movement. There was no visible ecchymosis or bruises on examination.

The left hip joint X-ray (figure 1) showed calcified mass overlying the posterior and lateral aspects of the left greater trochanter consistent with tumoural calcinosis. Besides tumoural calcinosis within the left greater trochanteric bursa, MRI of the left hip joint also showed large left gluteal haematoma $16 \times 9 \times 5.6 \mathrm{~cm}$ with diffuse oedematous changes involving gluteal musculature (figures 2 and 3). The patient had haemodialysis after the MRI to prevent systemic fibrosis. Laboratory testing

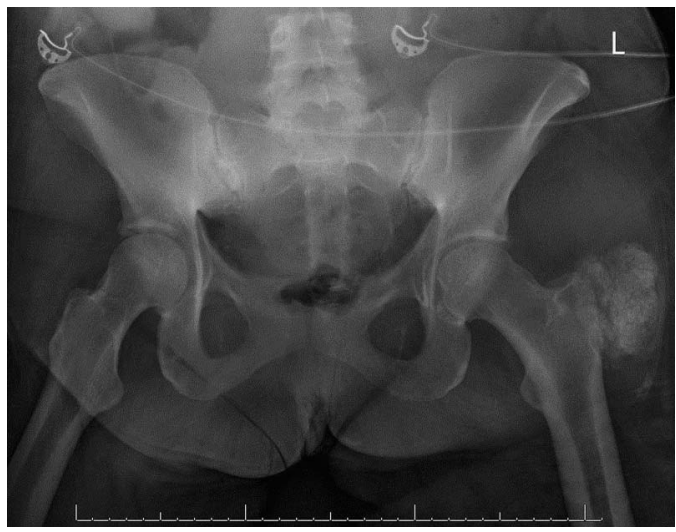

Figure 1 X-ray of the left hip joint showing calcified mass overlying the posterolateral aspect of the left greater trochanter consistent with tumuoral calcinosis.

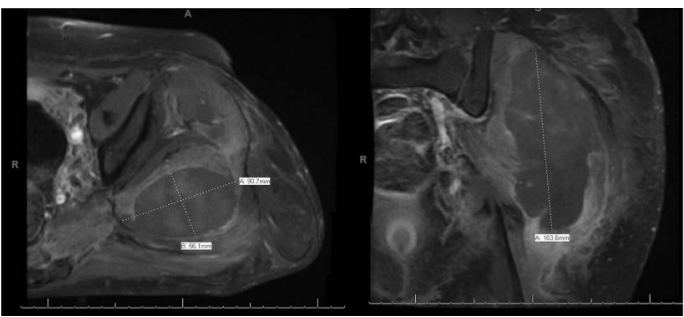

Dawood T, Bachuwa G. BMJ Case Rep Published online: [please include Day Month Year] doi:10.1136/bcr-2017219349

CrossMark
Figure $2 \mathrm{MRI}$ of the left hip joint showing large left gluteal haematoma $(16 \times 9 \times 5.6 \mathrm{~cm})$ with diffuse oedematous changes involving gluteal musculature.

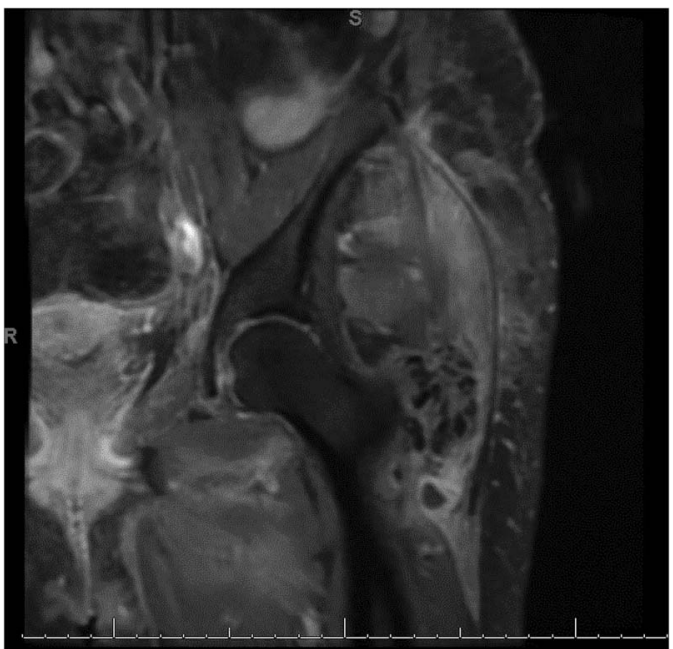

Figure 3 MRI showing left hip tumoural calcinosis.

showed secondary hyperparathyroidism with hyperphosphataemia. The patient was treated conservatively with analgesia and withholding antiplatelet therapy. As she had already completed 8 months of dual antiplatelet, ticagrelor was discontinued and aspirin was resumed after her pain resolved. The patient was discharged on phosphate binders.

Tumoural calcinosis is a rare disease characterised by calcium deposition in periarticular spaces. ${ }^{1}$ Secondary tumoural calcinosis is usually due to ESRD. ${ }^{1}$ It is usually a radiological diagnosis and

\section{Learning points}

Despite its great benefit in secondary prevention of myocardial infarction and coronary stent thrombosis, especially in patients with chronic kidney disease, dual antiplatelet therapy has an increased risk of bleeding and haematomas. Benefit versus risk should frequently be reassessed in all patients on dual antiplatelet.

- Secondary tumoural calcinosis is a benign condition that may be seen in end-stage renal disease patients. Radiologists and clinicians should be aware of the radiological appearance of this condition to avoid unnecessary workup and invasive procedures.

- Acute severe pain is not a usual manifestation of tumoural calcinosis; other causes should be considered. 
differentiating it from malignant causes is important to avoid unnecessary work-up. ${ }^{1}$ Management of secondary tumoural calcinosis is mainly medical by calcium and phosphorus restricted diets and phosphate binders. ${ }^{1}$

Tumoural calcinosis should not cause acute severe pain. Therefore, it is important to rule out other aetiologies. In our case, the cause of acute pain was the gluteal haematoma due to antiplatelet therapy. Spontaneous haematoma in patients on dual antiplatelet has been reported before. ${ }^{2}$

Ticagrelor is superior to clopidogrel in secondary prevention of coronary artery disease but has an increased risk of spontaneous bleeding. ${ }^{3}$

Contributors AA planned, designed, wrote and critically revised the manuscript. He prepared the images. He collected data. He had important role to facilitate the work between different authors. He also did the literature review. TD critically revised the manuscript and helped in collecting data. He also helped in selecting the images. GB planned designed wrote and critically revised the manuscript.

Competing interests None declared.

Patient consent Obtained.

Provenance and peer review Not commissioned; externally peer reviewed.

\section{REFERENCES}

1 Fathi I, Sakr M. Review of tumoral calcinosis: a rare clinico-pathological entity. World J Clin Cases 2014;2:409-14.

2 Bevan P, Menon A, Bunton R. Spontaneous chest wall hematoma with dual antiplatelet therapy. Can J Cardiol 2014;30:247.e1-1.

3 Wallentin L, Becker RC, Budaj A, et al. Ticagrelor versus clopidogrel in patients with acute coronary syndromes. N Engl J Med 2009;361:1045-57.

Copyright 2017 BMJ Publishing Group. All rights reserved. For permission to reuse any of this content visit http://group.bmj.com/group/rights-licensing/permissions.

BMJ Case Report Fellows may re-use this article for personal use and teaching without any further permission.

Become a Fellow of BMJ Case Reports today and you can:

- Submit as many cases as you like

- Enjoy fast sympathetic peer review and rapid publication of accepted articles

- Access all the published articles

- Re-use any of the published material for personal use and teaching without further permission

For information on Institutional Fellowships contact consortiasales@bmjgroup.com

Visit casereports.bmj.com for more articles like this and to become a Fellow 